\section{Medical Education in India}

India has been exporting doctors for over a hundred years. In the early part of this century she sent them to Arabia, Burma, China, Malaya, tropical Africa, the Caribbean, and to parts of South America in addition to catering for her own needs.

Apart from sentiment there are two reasons why medical education in independent India continues to be of great interest to Britain and to the world in general. Firstly, for some years" to come the staffing of the hospital division of the National Health Service will rely on a flow of Indian graduates who come here for higher studies. Secondly, India was the pioneer in dismantling the two-tier system of medical education-a matter still the subject of hot debate among those concerned with developing countries. Her licentiate doctors, with general education to matriculation standard followed by a four-year course in a medical "school," formed the backbone of the medical profession in India and provided most of her medical exports. These licentiates greatly outnumbered the medical graduates with their five years of instruction in a university medical " college" after two years spent in general and science studies after matriculation.

In 1936 like a bolt from the blue the minister of health in Madras, the late Dr. T. S. S. Rajan, ordered the closing down of the medical schools in his province, and his example was rapidly followed all over India. Two important commissions, both presided over by distinguished Indians, have reported on India's needs. The Bhore commission issued its monumental report near the end of the British régime and completely accepted the abolition of the "school "-educated doctor ; the Mudaliar commission in 1959 urged the provision of one medical college per five million inhabitants. The number of medical colleges in India has increased from 15 in 1947 (the year of independence) to 61 at the present time, and the annual output of graduate doctors has risen to about 5,000.

The Indian Institute of Manpower Research and the National Institute of Health Administration and Education have recently issued a report on Health and Medical Manpower, ${ }^{1}$ which, preceding the issue of the British Royal Commission's report ${ }^{2}$ by some months, provides a comprehensive survey of existing colleges, student-teacher ratios, sex distribution ratios, and the siting of colleges by provinces, with appendices giving details of curricula and a mass of statistical information. It lays emphasis on the persisting shortage of teachers and devotes particular attention to student wastage -both loss of students from dropping out of the course and waste of time or undue delay in completing the curriculum. That close on half pass within five years and $90 \%$ within six years and that only $6 \%$ do not pass at all compares favourably with some Western figures.

The great need for medical women in India in connexion with family planning projects and the reluctance of women in rural areas to accept male doctors is being met by an overall admission rate of $25 \%$ for women rising to $60 \%$ in the colleges at New Delhi. The retention of the term "allopathic medicine" to represent modern scientific medicine may surprise some readers, but a high proportion of the Indian population still prefer the ancient indigenous systems of medicine, and even some members of the Indian cabinet still oppose

\footnotetext{
1 Health and Medical Manpower: Development of Modern Medical Education in India and Student Wastage in Medical Colleges, 1967. Institute of Applied Manpower Research and National Institute of Health Administration and Education, New Delhi.

- Report of the Royal Commission on Medical Education, 1965-68, Cmnd. 3569. H.M.S.O.
}

modern medicine, vaccination, and other preventive measures.

The Health and Medical Manpower report is a valuable document, and, taken in conjunction with the Royal Commission's report, should help our Indian colleagues to grapple with their problems of both undergraduate and postgraduate medical education.

\section{Folic Acid and the Nervous System}

In contrast to the well-recognized neurological abnormalities produced by a low level of vitamin $\mathbf{B}_{12}$, the effects of a lack of folic acid on the nervous system are hard to define. It would be surprising if folic acid had no part to play, since it is present in the central nervous system, and its concentration in the cerebrospinal fluid is considerably higher than in the serum.

That folic acid could precipitate epileptic fits was shown by I. Chanarin and his colleagues ${ }^{1}$ in 1960. An epileptic patient had developed a megaloblastic anaemia as a result of long-term therapy with anticonvulsants. When folic acid was given to correct the folate deficiency the epilepsy became uncontrolled. E. H. Reynolds ${ }^{2}$ reported a series of 26 chronic epileptic patients who developed folic acid deficiency while on long-term anticonvulsant treatment and who showed an increase in the number of fits when given folic acid. In several of Reynolds's patients and in a patient reported by M. P. Anand, ${ }^{3}$ treatment with folic acid caused considerable improvement; they became brighter, showed an increased drive, and could sometimes return to work. Recently, folic acid therapy has been found to benefit the schizophrenia-like psychoses of epileptics. ${ }^{4}$ Epileptics show natural fluctuation both in the frequency of their fits and also in their' mental state ; and, although the latter is difficult to assess, folic acid seems to improve it either by directly antagonizing the effects of anticonvulsants or by some more fundamental effect.

Reynolds ${ }^{5}$ has sought to extend these observations to other causes of folate deficiency. Several studies have shown that among old people low levels of folic acid are quite common. ${ }^{6}$ $\mathrm{He}$ suggests that folate deficiency may cause some of the mental changes seen in old age, and that apathy leads to a deficient intake of folate in the diet and thus to a vicious circle. Nevertheless, not all authorities agree that folate deficiency is common in old people. Thus Girdwood and his colleagues ${ }^{8}$ were unable to find evidence of folate depletion in an elderly Scottish population. In a self-induced experimental folate deficiency $\mathrm{V}$. Herbert ${ }^{9}$ developed nothing more than some slight irritability and forgetfulness.

\footnotetext{
' Chanarin, I., Laidlaw, J., Loughridge, L. W., and Mollin, D. L., Brit. med. F., 1960, 1, 1099.

2 Reynolds, E. H., Lancet, 1967, 1, 1086.

3 Anand, M. P., Scot. med. F., 1964, 9, 388.

- Reynolds, E. H., Brit. F. Psychiat., 1967, 113, 911.

- Reynolds, E. H., Brain, 1968, 91, 197.

- Hurdle, A. D. F., and Picton Williams, T. C., Brit. med. f., 1966, 2, 202.

' Batata, M., Spray, G. H., Bolton, F. G., Higgins, G., and Wollner, L., Brit. med. F., 1967, 2, 667.

* Girdwood, R. H., Thomson, A. D., and Williamson, J., Brit. med. F., 1967, 2, 670.

- Herbert, V., Trans. Ass. Amer. Phycns, 1962, 75, 307.

10 Grant, H. C., Hoffbrand, A. V., and Wells, D. G., Lancet, 1965, 2, 763.

1 Horwitz, S. J., Klipstein, F. A., and Lovelace, R. E., Lancet, 1968, 1, 563
} 